\title{
FROM DEFAMILIARIZATION TO FOREGROUNDING AND DEFEATED EXPECTANCY: LINGUO-STYLISTIC AND COGNITIVE SKETCH
}

\author{
Yuliya Kupchyshyna*, Yuliya Davydyuk
}

Corresponding author*

Kupchyshyna, Yu. \& Davydyuk, Yu. (2017). From defamiliarization to foregrounding and defeated expectancy: linguo-stylistic and cognitive sketch. In Lege artis. Language yesterday, today, tomorrow. The journal of University of SS Cyril and Methodius in Trnava. Warsaw: De Gruyter Open, vol. II (2), December 2017, p. 148-184. DOI: 10.1515/lart-2017-0015 ISSN 2453-8035

\begin{abstract}
The article focuses on revealing the nature of defamiliarization, foregrounding, and defeated expectancy from a linguo-stylistic and cognitive perspective. It has been stated that defamiliarization, composed by different types of foregrounding and defeated expectancy as deviation, generated with a certain stylistic purpose are complex phenomena. The article highlights cognitive factors which ensure the creation of defamiliarization and defeated expectancy in the literary texts.
\end{abstract}

Key words: defamiliarization, foregrounding, defeated expectancy, stylistic device, linguo-stylistic aspect, cognitive aspect.

A linguist deaf to the poetic function of language and a literary scholar indifferent to linguistic problems and unconversant with linguistic methods are equally flagrant anachronisms (Roman Jakobson "Linguistics and Poetics")

\section{Introduction}

Russian Formalism is the name for a group of literary scholars and linguists who between 1916 and 1929, while most were still in their twenties, developed a series of innovative theoretical concepts, claims, models, and methodological norms concerning various aspects of the literary system and its study (Margolin 2005). Russian Formalism's major contributions can be approached in terms of literariness and 
"devices" that distinguish literary language from ordinary language: formalists saw literary works as consisting of material, whether linguistic or representational (i.e. events, characters, or ideas), that lack aesthetic value, and of stylistic and compositional devices (i.e. procedures and techniques) that possess such value. Along with literariness, the most important concept of the school was that of defamiliarization: instead of seeing literature as a reflection of the world, Victor Shklovsky and his Formalist followers saw it as a linguistic dislocation, or a "making strange" (Baldick 2008).

Ten years later, in 1926 the Prague School refined the theory of defamiliarization and developed a theory that afterwards became one of the central notions of decoding stylistics and a method which helped in constructing algorithms for the text analysis the theory of foregrounding. The term "foregrounding" or "actualization" comes from the works of outstanding Prague School linguists, such as Mukařovský, Havránek, Chizhevsky and Mathesius who were involved into the research of the literary and poetic language (Гавранек 1967; Матезиус 1967; Мукаржовский 1967; 1996). These scholars claimed that the relationships between literary and poetic language were primarily based on the fact that literary language was the background for poetic language, which displayed special distortion of linguistic parts of the literary text; this distortion was known as special violation of language norms (Блашкив 2006; Блашків 2010; Мукаржовский 1967).Within the analysis of poetic language, these scholars also investigated that poetic language was characterized by playing of meanings of words; the purpose of such playing was the "actualization" of these words (Блашкив 2006). The actualization of any components in poetic language means their foregrounding, i.e. using such language devices, which can draw attention and can be perceived as unusual and devoid of automatism (Гавранек 1967; Мукаржовский 1967; 1996).

This technique as well as the technique of defamiliarization creates a completely new principle of correct perception of the literary text: the reader needs to consider the 
literary work as a "new born viewer or listener" (Чижевський 2005: 391-402). McIntyre points out that "defamiliarizing a work of art or a text we make it stand out from the norm - it becomes foregrounded" (McIntyre 2003), thus, these two theories - the theory of foregrounding and defamiliarization - are considered to be interrelated (Давидюк 2015; Купчишина 2013a; 2015; Jeffries \& McIntyre 2010: 30-31; Miall \& Kuiken 1994; Simpson 2004: 50; van Peer 1986).

Taking everything into account, the present paper aims to analyse defamiliarization and foregrounding with its basic types as effective tools for literary analysis from linguo-stylistic and cognitive perspectives with special attention given to one of the most interesting and extraordinary type of foregrounding - defeated expectancy (deviation). Our methodology includes the combination of traditional (linguo-stylistic analysis) with the most recent conceptual techniques (reconstructing key concepts, building mental spaces and conceptual integration networks), which are directed into the search of new ways to discover and interpret the hidden meanings of a literary text. The combination of traditional with the most recent techniques is of great potential nowadays as it offers the scholar a set of tools for exploring different language units and interpreting literary texts / discourse (see works by Davydyuk \& Panasenko 2016; Panasenko 2014; 2015; Panasenko et al. 2017; Uberman 2016; Vorobyova 2017; Zykova 2016, etc.).

\section{Linguo-stylistic and cognitive aspect of defamiliarization in literary texts}

Imagery as a predominant feature of a literary text as well as a poetic one has always been in the focus of investigation of the poetics of fiction. Defamiliarization is viewed as one of the ways of creating such imagery in the text. As the author's stylistic device it is created by different types of foregrounding with the aim of concentrating the reader's attention and emotions on the object of perception from an unusual angle of the narrator's vision (Новикова 2006; Hakemulder 2006; Shklovsky 1929). 
According to Russian Formalism defamiliarization is the basic function of all devices (Якобсон 1987; Eikhenbaum \& Tynyanov 1985; Shklovsky 1929). Defamiliarization comprises both the slowing down and the increased difficulty (impeding) of the process of reading and comprehending and an awareness of the literary procedures (devices) causing them. Formalists assumed that habitual perception of reality is disrupted through distorting the temporal and causal order of events and the logical order of information and by seeing the familiar from a nonstandard perspective such as that of an outsider, a child, or an animal, etc. (Margolin 1994). For instance, in "Time out mind" the usual process of "drinking tea" can be perceived as something unknown, unfamiliar: "Inside this little pot in front of my face is a thick yellowish substance. A teaspoon of it comes towards me. I have no idea what it is and am reluctant to open my mouth" (Lapotaire 2004: 28).

As it has been determined above, defamiliarization is created by different types of foregrounding. The immediate effect of foregrounding is to estrange any object or phenomenon (ostranenie), thus, to achieve defamiliarization. One of the main functions of defamiliarization refers to the author's ability "to combine the child's sense of wonder and novelty with the appearances, which every day for perhaps forty years had rendered familiar" (Coleridge 1817: 85).

In linguopoetics, the interest in the problem of defamiliarization manifests in the scholars' appeal to the stylistic means of its implementation in the text, which extend and deepen already known ideas about the functioning of language units in the literary text. Investigations in the aspect of semantics result in division of non-standard semantic constructions into semantic anomalies, as a deviation from the linguistic norm and absurd statements that reflect human mind (Арутюнова 1998). In literary criticism the notion of defamiliarization is highlighted as a way of comic, ironic conceptualization of the world and is associated with such terms as deviation, contrast, effect of defeated expectancy, estrangement, alienation, deautomatization, 
Verfremdung (Бєлєхова 2002; Мукаржовский 1996; Олейникова 2013; Якобсон 1987; Shklovsky 1929).

Modern cognitive linguistic schools identify defamiliarization as a device which operates at different text levels: semantic, syntactic, and pragmatic. It unites all tropes and figures in one unusual and strange perception of reality (Бєлєхова 2002). The essence of metonymy or metaphor, parallelism or oxymoron can be seen in defamiliarized perception of the world (Eikhenbaum \& Tynyanov 1985). Moreover, defamiliarization creates cognitive dissonance (Dinsmor 1998). Cognitive dissonance is understood as intellectual conflict that arises between the reader's schema and text schema (Бєлсхова 2002). Defamiliarization contributes to the deautomatization of the process of the text analysis, causing the change of common schemas of knowledge in the reader's mind. This device transforms knowledge schemes that activate stereotypical verbal images and leads to the emergence of novel senses. If any literary text contains stereotypical images, the world, described in this text is perceived as known and familiar. Thus, defamiliarized images renew reader's scheme of information. The process of deautomatization requires cognitive efforts to interpret defamiliarized images and helps deeply understand them.

\subsection{Linguo-stylistic aspect of defamiliarization}

Defamiliarization provides a range of techniques aimed to reflect changes in states and perceptions and convey the reality by linguistic means (Sotirova 2016). The significance of defamiliarization consists in the representation of the phenomenon of increased reader's attention. For instance, in "Sudden story" by Robert Coover the notion of hunger is seen through the animal's (dragon's) perception - this is what we call animalistic subject of narration: "For the dragon everything was sudden. He was suddenly hungry and then he was suddenly eating something. Always, it was like the first time. Then, all of sudden, he would remembered having eaten something like that before: a certain familiar sourness <...> and suddenly, he would forget" (Coover 1986). The feeling of hunger is interpreted as something unknown, unfamiliar to the 
animal's imagination. The accumulation of stylistic devices not only intensifies the defamiliarized image of a growing starvation, but also creates stylistic convergence. Using the method of linguo-stylistic analysis we can determine that the image of hunger is based on such stylistic devices: hyperbole (for the dragon everything was sudden); simile (it was like the first time); antithesis (eating - hungry; for the first time - something like that before), which shows unstable animal's feelings; alliteration (sudden, suddenly, sudden story), which underlines suddenness of its hunger.

Defamiliarization can also be regarded as a method of alienation ("ostraneniya"), i.e. a linguistic, semantic phenomenon, which can be reflected in the genre of science fiction. In such case, there can be a unified cognitive model of creating an invented science fiction world which contains three objects: defamiliarization of time, place (for example, another planet), and an actant (Олейникова 2013). Such type of defamiliarization is determined as a cosmic subject of narration (Купчишина 2013; 2015). For instance, in Bradbury's "Dark they were and golden eyed" people's appearance (colour of skin, colour of eyes, etc.) may be different, depending on what distant planet they are (Mars, Venus): "Lying a bed, Mr. Bittering felt his bones shifted, shaped, melted like gold. His wife, lying beside him, was dark from many sunny afternoons. Dark she was, and golden, burnt almost black by the sun, sleeping, and the children metallic in their beds (Bradbury 2003). The cosmic angle of vision may also change the familiar perception of nature in "The wilderness": a) soil, grass, the sky, tree: "The soil was a strange colour of violet, and the grass was the faintest bit red, and the sky glowed like a gray diamond, and a strange crooked tree grew to one side, looking like an old woman with crystals in her white hair"; b) the sun as fire in "All summer in a day": "It was the color of flaming bronze and it was very large. It's like a fire; as a yellow coin: a coin large enough to buy the world with"; c) the sun as a flower in "All summer in a day": "She knew they thought they remembered warmness, like a blushing in the face, in the body, in the arms and legs and trembling hands. I think the sun is a flower that blooms for just one hour" (Bradbury 2003). 
The predominant devices forming defamiliarized images in the examples above are similes and metaphors (original, biomorphic) that underline the difference from stereotypical vision of appearance and nature. In another example, taken from Bradbury's "The illustrated man", the action takes place on Mars. Distant location influences on the perception of "a dream": in the given text fragment it is seen as a "kind woman" and a lasting feeling of kindness and warmth: "You won't care about anything but sleep and more sleep. Sleep will be like a woman to you. You will always go back to her, because she's fresh and good and faithful and she always treats you kindly and the same. You only wake up so you can think about going back to sleep" (Bradbury 2003). The major devices of the defamiliarized image are the anthropomorphic metaphor SLEEP IS A WOMAN and simile (Sleep will be like a woman to you).

\subsection{Cognitive aspect of defamiliarization}

Cognitive interpretation of defamiliarization was carried out on the basis of exploring cognitive models of defamiliarized images and their spaces applying the theory of conceptual integration (blending) (Купчишина 2014; 2015). This theory was developed by Fauconnier and Turner (2002) in order to improve the theory of conceptual metaphor proposed by Lakoff and Johnson (2003) and is widely spread in cognitive linguistics.

In its most basic form, a conceptual integration network consists of four connected mental spaces: two partially matched input spaces, a generic space constituted by structure common to the inputs, and a blended space that contains some elements from each input space. The blended space may also contain additional elements that can include new elements retrieved from long-term memory or resulting from the comparison of elements drawn from separate inputs, or from elaboration on the elements in the blended space. This emergent structure is formed by more specific cognitive operations - composition, completion and elaboration (Fauconnier 1997; Fauconnier \& Turner 2000; Turner 2007). Blending composes elements from the input 
spaces to provide relations that do not exist in the separate inputs. As a result, composition, completion, and elaboration lead to an emergent structure in the blend; the blend contains the structure that is not copied from the inputs (Fauconnier \& Turner 2002).

To show how the theory of conceptual integration works we chose a short story "The lady in the looking glass: a reflection" by the British modernist author Virginia Woolf. Interpretive readings of Woolf's stories make note of the hidden imagination. Phillips (2003), for instance, recognises Woolf's discovery of a new capability of imagination as her main achievement. Woolf's writings suggest that imagination, just because it is often anchored to a physical detail or a solid object, never allows us to go "unmoored into purely abstract consciousness" (Ibid.: 10). Vorobyova's analysis of Woolf's short story proceeds from the assumption that, to a great extent, the specificity of literary imagination results from modifications and disturbances (Vorobyova 2005; 2017). Their presence might be found in the story's texture via various means of foregrounding and defamiliarization, employed by Woolf to achieve an aesthetically satisfying structure by other means (Lehman 1975).

The story "The lady in the looking glass: a reflection" describes the images reflected in a mirror situated in a woman's dressing room. The first question which must be asked is the identity of the lady in the looking glass. In the story she calls herself Isabella Tyson, but certain clues lead one to believe that she may be someone else. The narrator uses a looking glass as a metaphor for the lady's character. The play of light and shadow reflects modern ideas about the fluidity of the character. A person's character is changeable and is in constant motion. In contrast, the image of the house exterior, as reflected in the looking glass, is peaceful. Applying this metaphor to the split self, the interior image of the house reflects a deep interior of the self, constantly changing and adapting, hidden away from the world behind the doors. The narrator's attention is drawn from the house to its mistress, Isabella. First, she reviews the established facts about Isabella's life: that she is single, rich and travels a lot. The narrator tries to 
imagine what the nature of Isabella's thoughts must be, and conjectures that they will be like the drawing room - full of shadows and light. And then Isabella sees her reflection in the mirror, returning from the walk in the garden. The narrator now has a new vision of the truth about Isabella. She is alone; she has no friends; and the letters are all bills - which Isabella does not even bother to open.

Conceptual integration network of Woolf's "The lady in the looking glass: a reflection" is a mirror type of integration, in which a common organizing frame is shared by all spaces in the network (Fauconnier \& Turner 2002). With the help of linguo-stylistic analysis we determine the key words of the story: life, emptiness, soul, looking-glass, which verbalize contrasted concepts: LONELINESS vs BUSINESS; POVERTY vs WEALTH; MIND vs EMPTYNESS, explicitly indicated in the text. It is stated whatever concerns life, death, or another abstract notion is, in Woolf's imagination, conceptually extended or elaborated. Whatever concerns the working of the mind appears as the result of a combination of conceptual metaphors. Wherever the issue of knowledge is brought up, conceptual stereotypes are being questioned (Vorobyova 2005).

The image of "mind" is the object of defamiliarization, perceived through the mirror by the narrator: "<...> she was filled with thoughts. Her mind was like her room in which lights advanced and retreated, came pirouetting and stepping delicately, spread their tails, pecked their way; and then her whole being was suffused, like the room again <...>" (Woolf 1972). Using linguistic and cognitive operation of specification and extension we reconstruct several modified conceptual metaphors: MIND IS AN OBJECT $\rightarrow$ MIND IS A CONTAINER $\rightarrow$ MIND IS A ROOM;

The image of "reflection": "Here was the woman herself. She stood naked in that pitiless light. And there was nothing. Isabella was perfectly empty. She had no thoughts. She had no friends. She cared for nobody. As for her letters, they were all bills. Look, as she stood there, old and angular, veined and lined, with her high nose 
and her wrinkled neck, she did not even trouble to open them" (Woolf 1972) $\rightarrow$ REFLECTION IS STATE $\rightarrow$ REFLECTION IS TRUTH.

In the presented cognitive analysis the conceptual integration network is used as a tool for decoding defamiliarization. Matching the two inputs and projecting selectively from these two input spaces into the fourth mental space, we reconstruct the blended space: a new meaning of the abstract notion "mind" (see Fig. 1).

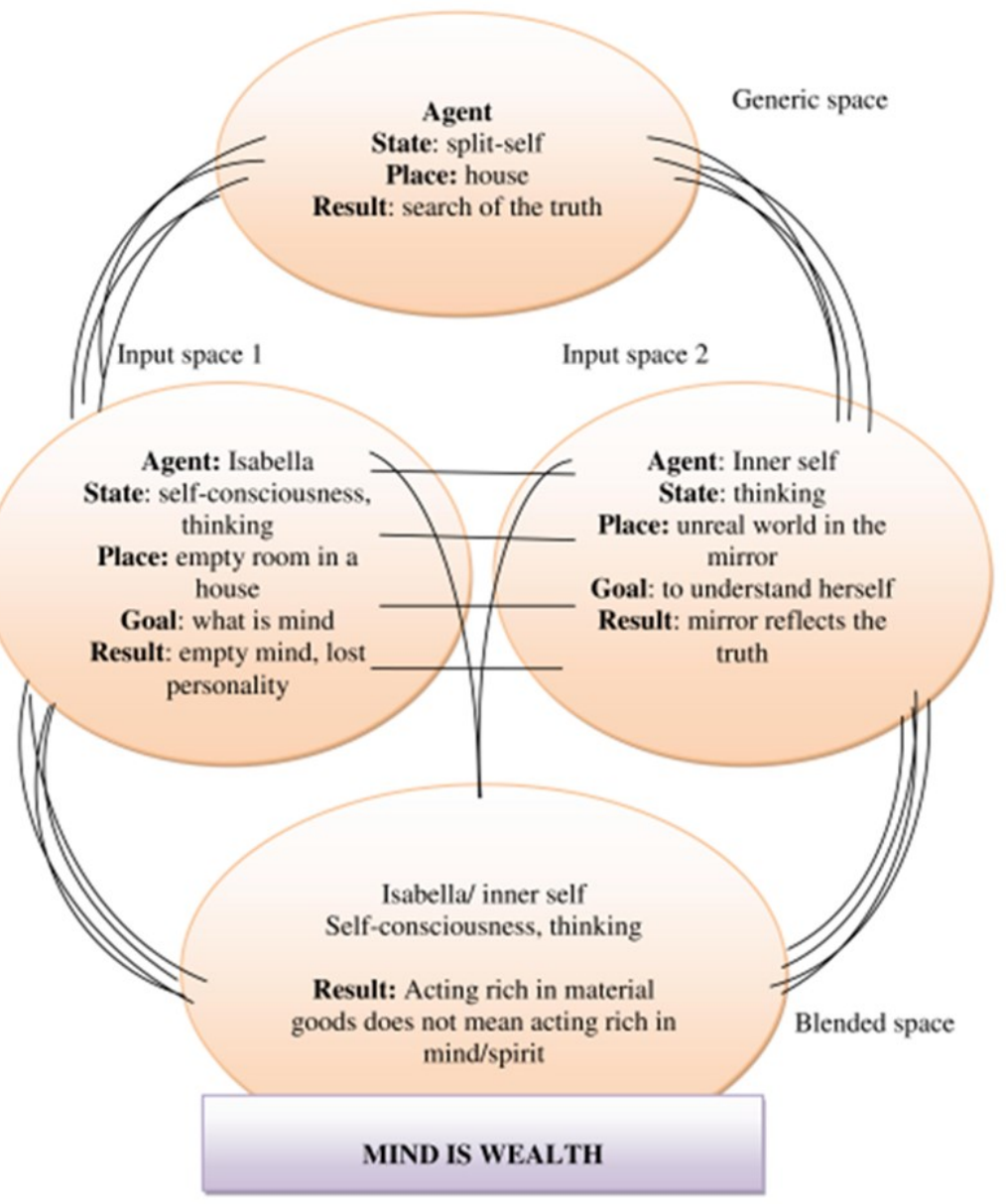

Figure 1. Conceptual integration network: Mind is wealth

Newly created metaphors are based either on rich images or on a conceptual breakthrough in Woolf's short stories (Vorobyova 2005). The conventional conceptual metaphor MIND IS AN ABILITY TO THINK has undergone modifications due to linguistic and cognitive operation of extension as follows: MIND IS WEALTH, meaning acting rich in material goods does not mean acting rich in mind. It is important 
to say that the image of the mirror is also symbolic in Woolf's stories. It serves as a tool for seeing something unexpected, strange and hidden. It has a negative effect on Isabella's unreal world, reflected in the mirror. Such stylistic device as ring repetition (people should not leave looking-glasses hanging in their rooms), which can be observed at the beginning and the end of the story, serves as a tool to create a circle and thus activates the reflection of the truth.

Thus, the blending analysis can manifest what readers obtain from their own knowledge domains, and it is possible to discover how the author's own vision can be distinguished. The cognitive operation of modification is defined as predominant in the creation of defamiliarized images, because it is aimed at the transformation of the conventional conceptual metaphor, which leads to the emergence of novel senses.

\section{The notion of foregrounding and its basic types}

After the Prague School, the theory of foregrounding has been enlarged and worked out by such scholars, as Arnold (Арнольд 1999; 2002), Leech (1965; 2007; 2008), Levin (1965), Short (1996), van Peer (1986), etc. Foregrounding can occur at any language level, e.g., at phonetic, grammatical, or semantic; it can also be observed in everyday language, but in fiction, foregrounding is more systematic and structured: in everyday speech, communication is a primary objective and "foregrounded" structures are not usually involved, while the aim of the literary language is to describe unusually every day communication (Miall \& Kuiken 1994). Actualization creates an aesthetic context and performs a variety of semantic functions, one of which is to increase the expressiveness and establish a hierarchy of values and elements in the text, that is to foreground crucially important parts of the message or text. The principle of foregrounded structures ensures the unity and consistency of the literary text structure, establishing the links between the whole text and its parts. 


\subsection{The main interpretations of foregrounding}

There are two main interpretations of foregrounding - according to the views of Russian and British linguistic schools correspondingly. The Russian linguist Arnold claimed that foregrounding was created by different types of contextual consistency; here she included such notions, as coupling, convergence, defeated expectancy, strong positions of the text, thematic net, and different kinds of repetitions (Арнольд 1999; 2002). Using these types of foregrounding, a researcher may consider the unity of form and content of the text at the level higher than the level of stylistic devices, because these methods of foregrounding are created with the help of blocks of stylistic devices. Instead, according to British scholars, foregrounded parts of the text, which are highly memorable and interpretable, can be achieved in two ways - via linguistic deviation and parallelism. Linguistic deviation is interpreted as an unexpected irregularity and parallelism - as unexpected regularity (Jeffries \& McIntyre 2010: 31; McIntyre 2003; Simpson 2004: 50).

\subsection{The basic types of foregrounding}

Foregrounding created by deviation is called paradigmatic foregrounding; foregrounding generated by parallelism is called syntagmatic foregrounding (van Peer 1986: 14). In addition to these types of foregrounding, there are also external and internal types of foregrounding (Levin 1965) as well as qualitative and quantitative (Leech 2007; 2008). External and / or qualitative foregrounding is considered to be a deviation from the language code itself, for instance, the violation of certain grammatical rules and conventions of the language or violation of cultural and esthetical norms. Internal and / or quantitative foregrounding is considered to be a deviation from the expected frequency or the norm within the literary text (Leech 2007: 39; Levin 1965; van Peer 1986). According to the views of van Peer, the main features of foregrounding are its novelty, uniqueness and unexpectedness. It is a pragmatic concept that dynamically integrates the author, his / her literary text and the reader (van Peer 1986). On the one hand, certain "foregrounded" parts of the work will push the reader to interpretation and evaluation of the work of art, but, on the other hand, the 
reader will want to search such "foregrounded" parts of the work to satisfy his / her aesthetic pleasure during the reading process. In the light of the above mentioned, the theory of foregrounding can be connected with the theory of figure and ground, where foregrounding will be the figure against the ground, represented by the literary text (Щирова 2009: 733; Щирова, Гончарова 2007: 165-167; Stockwell 2002: 15-20; van Peer 1986: 20-21).

Hence, it may be concluded that foregrounding and its basic types play an important role both in stylistics and the theory of text interpretation: they reinforce the emotional and aesthetic impact on the reader, prolong the reader's pleasure of the literary text and promote better memorization of information, presented in the text.

\section{Defeated expectancy as the most striking type of foregrounding: linguo-stylistic and cognitive aspect}

Defeated expectancy, also known as the effect of defeated expectancy (Арнольд 2002) or deviation (Jeffries \& McIntyre 2010; Leech 2008; Leech \& Short 2007), is highly widespread in poetic and literary texts. Originally, the term "defeated expectancy", goes back to Jakobson who called it "dressing" to the literary text (Якобсон 1987: 85). Having analyzed grammatical parallelism in poetry, Jakobson assumed that the system of grammatical parallelisms and contrasts strike the eye of the reader, so that they might serve as poetic devices, greatly suggested and enriched by poets. Jakobson, following Baudelaire and E.A. Poe beliefs, claimed that "on the one hand, regularity and symmetry are primordial needs of the human mind, but, on the other hand, slight irregularities, which emerge against the regularities, are also necessary for creating literary effect" (Ibid.: 85).

Nowadays defeated expectancy can be treated as a general principle of any speech changes, created with a certain stylistic purpose and deviated from the norm. The term "deviation" is used by British scholars, who consider it the "occurrence of unexpected irregularity in language that results in foregrounding" (Jeffries \& McIntyre 2010: 31; 
Simpson 2004: 50). British linguists, namely Leech (1969), singled out eight types of deviation, which are distinguished at three main language levels: realization, form, and semantics. Realization is carried out by phonology and graphology, form comprises grammar and lexicon, and semantics is expressed by denotative or cognitive meaning. Thus, these types are called phonological, graphological, lexical, grammatical, semantic, dialectal, register, and historical deviations (Ibid.).

Defeated expectancy is not only known as one of the main types of foregrounding (Арнольд 2002; Маслова 1991; Хазагеров \& Ширина 1994; Jeffries \& McIntyre 2010; Leech 1969; van Peer 1986), but it is also regarded as: 1) a stylistic device (Арнольд 1999; 2002; Риффатер 1980); 2) a psycholinguistic phenomenon (Донгак 2000); 3) an emotive component in the literary text structure (Богин 2001); 4) a mental space phenomenon (Давидюк 2013a; 2015; Davydyuk 2013). Let us consider all these approaches in detail.

\subsection{Defeated expectancy as a stylistic device}

As a stylistic device, defeated expectancy is decoded as violation of the linearity of language, i.e. when elements of low predictability appear in the context of the ordered elements. Such low elements are always unpredictable, that is why they require enhanced activity and attention of the reader (Арнольд 1999: 239). Defeated expectancy can be implemented at all levels of language through various linguistic devices, e.g., at the lexical level, it may be comic authors' neologisms, jargons or vulgarisms, used in the literary style, as they have a low degree of predictability or words of high poetic style introduced in a conversational style; at the syntactic level defeated expectancy can be created by unexpected appearance of sentences with inversion; at the phonetic level this phenomenon may be created by abrupt changes in metres of the verse, thus transforming its syntactic and poetic organization (Арнольд 2002: 57). Moreover, defeated expectancy may occur in strong positions of the literary text, namely in the heading, at the beginning or at the end of the text. Effectiveness of defeated expectancy as a stylistic device depends not only on the skills of the author, 
but also on the linguistic nature of the stylistic device. In the recent years, studies, carried out in this area, have demonstrated that defeated expectancy may be generated via zeugma, oxymoron, and anticlimax (Ветвинская 1975); literary paradoxes, parallelisms, and various types of illogic (Маслова 1991); antiphrasis, antimetabole, puns, and the completion of instrumentation (Хазагеров \& Ширина 1994); irony, zeugma, and paradox (Лапшина 2013).

\subsection{Defeated expectancy as a psycholinguistic phenomenon}

Defeated expectancy has bilateral nature of stylistic device and psycholinguistic phenomenon, since it occurs through the interaction of two opposing phenomena of psycholinguistic nature - predictability and unpredictability (Донгак 2000). Unpredictability is achieved when the automatic interpretation process slows down or stops, thus making the unpredictable elements "foregrounded". In this case, the attention of the reader is attracted not only by the information content of the text, but also by other text qualities, which are usually not fixed in the standard expressions sound effects, similarities and differences of elements in their arrangement and content, and recurrence of these elements in the text. Identification and perception of these additional characteristics largely determines the impact of the literary text on the reader.

One of the scholars who considered defetead expectancy to be a stylistic device based on unpredictability was Michael Riffaterre (1980). The scholar expressed the opinion that the likelihood of elements, arisen in a written chain of the text, is different, that is why using the sequence analysis, one can predict to some extent the appearance of those elements in a chain. As the reader can interpret the text differently (reader's interpretation may contradict the intentions of the author), the author must "control his decoding by encoding", trying to draw the reader's attention to those elements, which seem important. And since the "predictability leads to elliptic decoding, the essential elements have to be unpredictable" (Риффатер 1980: 73). According to the author, predictability can lead to superficial reading; unpredictability demands attention: the 
intensity of perception must accord with the intensity of the message. Unpredictability plays an important role in stylistic context, which is considered by the scholar as "a linguistic model, which is suddenly violated by unpredictable element" (Ibid.: 87).

In other words, a stylistic context is a linguistic norm and a stylistic device is a deviation from it. The stylistic context creates defeated expectancy, which is stimulated by intense expectation, i.e. by a special orderliness of the context. The more contrastive the context is against the unpredictable element, the more artistic effect is created by the introduction of this element in the context. This allows answering the question why the same language element, having a high stylistic potential in one context, loses it in another context.

\subsection{Defeated expectancy as an emotive component}

From the point of view of literary text structure, defeated expectancy is an important stylistic constituent of connectivity, hence predictability / unpredictability plays a significant role in establishing a metatextual cohesion of text construction (Богин 2001: 547). Mechanisms of reader's relationship with the text are based on expectation, i.e. regulated expectancy of meanings in a predicted interaction with the text: during the reading process, the recipient may imagine what he / she "will see" hereinafter, based on contextual guess or internalization of context. If the following phrase does not match the previous one, there is a violation of expectation, so, it is noteworthy that defeated expectancy can be seen as a conflict of expected and actual perception. Therefore, the subsequent interpretation of the literary text requires more efforts from the recipient, and thus, evokes more emotions during the process of perception. So, defeated expectancy has an important function - making the mechanism of expressiveness and emotional impact on the reader's consciousness. In the light of the above mentioned, defeated expectancy or deviation can be seen as an emotive component in the structure of the literary text. 


\subsection{Defeated expectancy as a mental space phenomenon}

From a cognitive perspective, defeated expectancy is considered to be a mental space phenomenon (Davydyuk 2013; Давидюк 2013a; 2015). The concept of mental spaces was developed by Fauconnier (1994; 1997; 2007), who defined mental spaces as ordered sets of elements (a, b, c,), which are open for replenishing of new elements and relations between them accordingly (Fauconnier 1994). Mental spaces are models of discourse understanding; they are interconnected within it and can be modified to the extent of its deployment as fragments, pieces of text worlds. Mental spaces are based on the principle of Identification or Access principle of one mental space through another, and they are constructed for understanding counterfactual statements, artefacts or local contexts of discourse. In the theory of mental spaces we build a base or real space of mental representation of all what we perceive. Any set of operations or actions that occur in real space create a projected, hypothetical space, i.e. mental spaces are compact formatted knowledge in our minds. Hence, defeated expectancy is seen as a conflict of mental spaces, in which certain actions or set of operations that take place in real space are not relevant to a certain action or set of operations that take place in a hypothetical or expected space (Davydyuk 2013; Давидюк 2013a; 2015).

For instance, in "A comedy in rubber" by O. Henry there is a basic mental space - real one in which the main characters - William and Violet - meet each other in the street of the city to contemplate with special interest others' grief and accidents: "William Pry was the first on the spot. He was an expert at such gatherings. With an expression of intense happiness on his features, he stood over the victim of the accident, listening to his groans as if to the sweetest music" (O. Henry 1908). Young people immediately fall in love with each other and decide to get married, but they cannot get to their own wedding, because they become "victims" of their habit - they come to the church as witnesses to contemplate their own wedding: "William Pry and Violet Seymour, creatures of habit, had joined in the seething game of the spectators, unable to resist the overwhelming desire to gaze upon themselves entering, as bride and bridegroom, the rose-decked church" (Ibid.). The final part of the story causes the building of the 
second, hypothetical space, in which young people "would have got married", but had not done it. Consequently, this situation generates a counterfactual expression in mental spaces (MS (If_)) "Young people would have got married if they had not been slaves of their habits" (see Fig. 2).

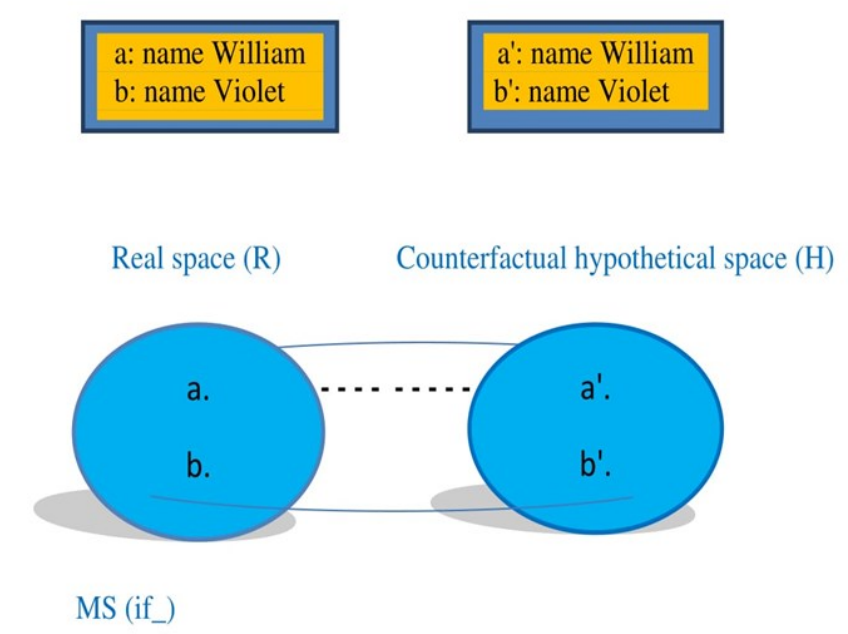

Figure 2. Model of mental spaces in O. Henry's "A comedy in rubber"

As shown in figure 2, the two main roles of mental spaces - the main characters of the story - are linked by the principle of Identification or Access principle: in real space (R-space) there are William and Violet, in the hypothetical or expected space (H-space) their doublets respectively - William' and Violet'. This happens due to the fact that the Access principle "states that an expression which names or describes an element in one mental space can be used to access a counterpart of that element in another mental space" (Fauconnier 2007: 353).

We would like to emphasize that the most striking defeated expectancy for the reader is when it is found at the semantic language level and in the plot structure of the literary text. For instance, in O. Henry's "The pendulum", the main protagonist John Perkins, who lives an average married life with his wife always stays at home, every night, at a quarter to nine does the same thing: he goes to his friends to play pool. Every night his wife asks him the same phrase: "Now, where are you going, I'd like to know, John Perkins?" "Thought I'd drop up to McCloskey's," he would answer, "and play a game 
or two of pool with the fellow" (O. Henry 1907). But one evening, having returned from work, John noticed a mess in the apartment, and what was the unexpected point for the hero - his wife was not at home: she left a note, saying that she went to visit her ill mother. John could not find a place in the apartment, everything reminded him of his wife, and without her he even felt himself between life and death: "Now, without warning, she was gone, vanished, as completely absent as if she had never existed. Of course it would be only for a few days, or at most a week or two, but it seemed to him as if the very hand of death had pointed a finger at his secure and uneventful home" (Ibid.). The situation suddenly turned out to be unexpected for the reader: John decides that as soon as his wife returns home, everything will be different: he will pay more attention to her and forget about gatherings at the friend's house. But the narrative ends most unexpectedly for the reader and for the protagonist - his wife suddenly returns at the very moment when John decides to change their family life. As this happens, the hero once again, as before, desperately needs to play pool with his friends: "The door opened. Katy walked in carrying a little hand satchel. John stared at her stupidly. "My! I'm glad to get back," said Katy. "Ma wasn't sick to amount to anything" $<\ldots>$ John Perkins looked at the clock. It was 8.15. He reached for his hat and walked to the door. "Now, where are you going, I'd like to know, John Perkins?" asked Katy, in a querulous tone. "Thought I'd drop up to McCloskey's," said John, "and play a game or two of pool with the fellows" (Ibid.).

The unexpected end of this story causes the emergence of defeated expectancy in the reader's conscience, because neither the reader nor the protagonist expected that his wife would be back so quickly. In the middle of the story, when John begins to feel remorseful about how he has treated his wife, the reader expects that the main hero will change his attitude toward marriage. But despite all his good intentions, John never follows through with changing his routine. The ironic feelings of the main character and his abrupt change of mood, super-fast transition from the trivial routine-tosuffering and vice versa arouses unpredictable emotional reaction of the reader. We analyse defeated expectancy in this story as a stylistic device and one of the main types 
of foregrounding, implemented at the semantic language level as well as in the plot structure of the text, via irony that is embodied in the change and game of feelings of the main character through the whole story; a personified metaphor (hand of death had pointed a finger), which personifies an abstract concept (death) and creates common conceptual metaphor, as DEATH IS A HUMAN BEING; frame repetition of the two key parallel phrases which we encounter at the beginning and end of the story; a double antithesis, which is embodied in a sharp contrast between everyday

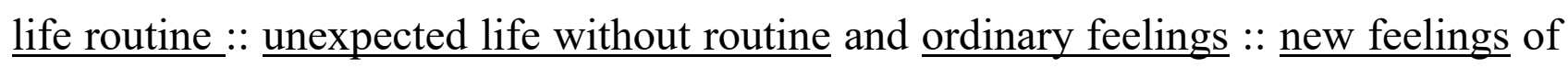
the protagonist, which may include appreciation, remorse, guilt, change, etc. towards his wife and family life in general. All these stylistic devices are "foregrounded" by the author with the aim to create comic effects that will draw readers' attention.

The basic concept of this work - the concept of LOVE that slowly swings like a pendulum, correlating with the title of the story - "The pendulum", finally fails to exist and turns into the family routine, which is inherited in the main protagonist and is clearly demonstrated by the two key phrases of the story: "Now, where are you going, I'd like to know, John Perkins?" asked Katy, in a querulous tone. "Thought I'd drop up to McCloskey's," said John, "and play a game or two of pool with the fellows". The above mentioned linguo-stylistic analysis of the story shows that defeated expectancy may be realized in the text for the hero as well as for the reader; moreover, throughout the story it may be realized several times via different stylistic devices, which have the "unexpected or contrasted element" in their structure, e.g., the figures of contrast (antithesis, paradox) or figures of inequality (e.g., zeugma, pun).

Thus, we regard defeated expectancy as a complex notion, which cannot be considered as a simple deviation from the norm, as it can occur at all levels of language as well as in all structures of the text (e.g., semantic, plot, etc.), greatly attracting readers' attention and having strong emotional influence on them. 


\section{Conclusions and discussion}

The literary text is a systematic, multidisciplinary phenomenon with different processes operating within it, which lead to actualization, and therefore, to deautomatisation of the perception and transformation of literary speech. Such transformed structures are perceived as a contrast between the most frequent use of language elements and new meanings that arise in the literary context. These new meanings are created by defamiliarization and foregrounding with defeated expectancy as one of its basic type.

Despite differences between linguistic schools, both defamiliarization and foregrounding can be defined as the unity of form and content of literary texts generated by the linguistic and cognitive mechanisms of revealing novel and implied conventional senses of the literary texts, as well as by narrative devices. The major manifestations of the defamiliarized world comprehension are considered to be biomorphic and anthropomorphic metaphors, which denote defamiliarized objects via the physical experience of people / animals. Different tools can be applied to reveal the cognitive nature of defamiliarization. The results of a cognitive analysis show that the conceptual integration theory is equipped with the techniques, which can be used to analyze defamiliarization in order to provide insights into the mechanisms which regulate their creation and cognitive organization. This theory may also give clues about the ways in which we interpret modified and blended figurative expressions. Hence, defamiliarization as the author's original device constrains horizons through cognitive operations as well as modifies and reorganizes the perception of the reality.

In turn, defeated expectancy as one of the main types of foregrounding is an important element of a text structure, because it provides text consistensy, establishing the links between the text and its parts. Being a stylistic device itself, defeated expectancy may be generated via different stylistic devices, mainly via the figures of contrast or inequality, because they are such devices that contain unexpected elements in their structure. The cognitive nature of this type of foregrounding can be revealed through 
the mechanisms of the theory of mental spaces, which helps show the violation or conflict between real and expected structures, for defeated expectancy is considered to be the violation of expectation.

A general conclusion that may be drawn from the linguo-stylistic and cognitive analysis of the above-presented material is that defamiliarization as the unique stylistic device, and defeated expectancy, as one of the most striking types of foregrounding are far more than stlylistic devices and deviations from the norm. These devices are complex and original phenomema, which circulate at any language level and especially used in literary or poetic texts and their perspective is still to be investigated.

\section{References}

Arnold, I.V. (1999). Semantics. Stylistics. Intertextuality: [collection of articles]. St. Petersburg: St. Petersburg University Publishing house. / Arnold I.V. Semantika. Stilistika. Intertekstualnost': [sbornik statej]. Sankt-Peterburg: Izdatel'stvo SanktPeterburgskogo universiteta. / Арнольд И.В. Семантика. Стилистика. Интертекстуальность: [сб. статей]. Санкт-Петербург: Издательство СанктПетербургкого университета.

Arnold, I.V. (2002) The stylistics of modern English language. Moscow: Flinta. I Arnold I.V. Stilistika sovremennogo anglijskogo yazyka. Moskva: Flinta. / Арнольд И.В. Стилистика современного английского языка. Москва: Флинта.

Arutiunova, N.D. (1998). The language and the world of man. Moscow: The language of Russian culture. / Arutyunova N.D. Yazyk i mir cheloveka. Moskva: Yazyki Russkoj kultury. / Арутюнова Н.Д. Язык и мир человека. Москва: Языки русской культуры.

Baldick, C. (2008). The Oxford dictionary of literary terms. Oxford: Oxford University Press.

Belekhova, L.I. (2002). Verbal poetic image from the historical typological perspective: A cognitive aspect (A study of American poetry). Kherson: Ailant. I Byelyekhova L.I. Slovesnyj poetychnyj obraz v istoryko-typologichnij perspektyvi: 
lingvokognityvnyj aspect. Kherson: Ajlant. / Бєлєхова Л.І. Словесний поетичний образ в історико-типологічній перспективі: лінгво-когнітивний аспект (на матеріалі американської поезії). Херсон: Айлант.

Blashkiv, O.V. (2010). Czech and Slovak culture in the life and scientific heritage of D. Chyzhevsky. Siedlce: Instytut Filologii Polskiej Uniwersytetu PrzyrodniczoHumanistycznego / Blashkiv O.V. Ches'ka i slovats'ka kultura v zhitti ta naukovij spadschini D. Chizhevskogo. Siedlce: Instytut Filologii Polskiej Uniwersytetu Przyrodniczo-Humanistycznego. / Блашків О.В Чеська і словацька культура в житті та науковій спадщині Д. Чижевського. Siedlce: Instytut Filologii Polskiej Uniwersytetu Przyrodniczo-Humanistycznego.

Blashkiv, O.V. (2006). The creation of Dmitry Chizhevsky in the context of the ideas of the Prague Linguistic Circle. In Literary collection, 26-27, p. 107-120. / Blashkiv O.V. Tvorchestvo Dmitriya Chizhevskogo v kontekste idej Prazhskogo lingvisticheskogo kruzhka. In Literaturovedcheskij sbornik, 26-27, s. 107-120. I Блашкив О.В. Творчество Дмитрия Чижевского в контексте идей Пражского лингвистического кружка. In Литературоведческий сборник, 26-27, p. 107-120. Bogin, G.I. (2001). Finding the ability to understand: the introduction to hermeneutics. Moscow: Tver' Publishing house. / Bogin G.I. Obretenie sposobnosti ponimat': vvedenie v germenevtiku. Moskva: Izdatel'stvo Tver'. / Богин Г.И Обретение способности понимать: введение в герменевтику. Москва: Издательство Тверь. Bradbury, R. (2003). Bradbury Stories: 100 of his most celebrated tales. New York: William Morrow.

Chizhevsky, D.I. (2005). About the "overcoat" by Gogol. In Philosophical works in four volumes, 3, p. 384-402. / Chizhevskyj D.I. Pro "shinel"' Hoholya. In Filosofski tvory u chotyriokh tomakh, 3, s. 384-402. / Чижевський Д.І. Про "Шинель" Гоголя. In Філософські твори у чотирьох томах, 3, с. 384-402.

Coleridge, S. (1817). Biographia literaria. In Text and meaning. Burwick, F. (ed.). Ohio: Ohio State University Press, Columbus.

Coover, R. (1986). A sudden story. In Sudden fiction: American short-short stories. Shapard, R. \& Thomas, J. (eds.). Salt Lake City: Gibbs Smith. 
Davydyuk, Yu.B. (2013). Defeated expectancy as a mental space phenomenon. In International English studies journal. Studia anglica resoviensia. Rzeszów: Wydawnictwo Uniwersytetu Rzeszowskiego, 10, p. 7-15.

Davydyuk, Yu.B. (2013a). Defeated expectancy through the prism of mental space theory. In Visnyk of Taras Shevchenko national university of Lugans'k. Philological sciences, 14 (1), p. 28-32. / Davydyuk Yu.B. Efekt oshykanogo ochikuvannya kriz' pryzmu teoriyi mental'nykh prostoriv. In Visnyk Luhans'koho natsionalnoho universytetu imeni Tarasa Shevchenko. Filologichni nauky, 14 (1), s. 28-32. / Давидюк Ю.Б. Ефект ошуканого очікування крізь призму теорії ментальних просторів. In Вісник Луганського національного університету імені Тараса Шевченка. Філологічні науки, 14 (1), с. 28-32.

Davydyuk, Yu.B. (2015). Defeated expectancy in semantic, temporal, and plot structure in the English literary text. Thesis for the Candidate Degree in Philology, Speciality 10.02.04 - Germanic Languages. Kyiv: Kyiv National Linguistic University. / Davydyuk, Yu.B. Efekt oshukanoho ochikuvannia u semantychniy, temporal'niy ta siuzhetniy strukturi anglomovnoho khudozhnioho tekstu. Dysertatsiya na zdobuttia vchenoho stupenia kandydata filologichnykh nauk. Kyiv: Kyivs'kij natsional'nyj lingvistichnyj universytet. / Давидюк, Ю.Б. Ефект ошуканого очікування у семантичній, темпоральній та сюжетній структурі англомовного художнього тексту / Дис. ... канд. філол. наук / Київ: Київський національний лінгвістичний університет. 10.02.04 - германські мови.

Davydyuk, Yu. \& Panasenko, N. (2016). Figuring the male and female: fire and water in Bradbury's (science) fiction. In Lege artis. Language yesterday, today, tomorrow. The journal of University of SS Cyril and Methodius in Trnava. Warsaw: De Gruyter Open, 2016, vol. I (1), June 2016, p. 4-74. DOI: 10.1515/lart-2016-0001

Dinsmor, D. (1998). Mental spaces from functional point of view. In The language and intelligence. Moscow: Progress, p. 385-410. / Dinsmor D. Mental'nye prostranstva s funktsional'noj tochki zreniya. In Yazyk i intellekt. Moskva: Progress, s. 385-410. I Динсмор Д. Ментальные пространства с функциональной точки зрения. In Язык и интеллект. Москва: Прогресс, с. 385-410. 
Dongak, S.B. (2000). Defeated expectancy as a stylistic problem (to the formulation of the question). In Speech communication (theoretical and applied aspects of speech communication), 3 (11), s. 110-117. / Dongak S.B. Obmanutoye ozhidaniye kak stilisticheskaya problema ( $\mathrm{k}$ postanovke voprosa). In Rechevoye obscheniye (teoreticheskiye i prikladnyye aspekty rechevogo obscheniya), 3 (11), s. 110-117. I Донгак С.Б. Обманутое ожидание как стилистическая проблема (к постановке вопроса). In Речевое общение (теоретические и прикладные аспекты речевого общения), 3 (11), с. 110-117.

Eikhenbaum, B. \& Tynyanov, Yu. (1985). Russian prose. Ardis Publishers. Fauconnier, G. (1994). Mental spaces: aspects of meaning construction in natural language. Cambridge: Cambridge University Press.

Fauconnier, G. (1997). Mapping in thought and language. Cambridge: Cambridge University Press.

Fauconnier, G. (2007). Mental spaces. In The Oxford handbook of cognitive linguistics. Cuyckens, H. \& Geeraerts, D. (eds.). Oxford: Oxford University Press, p. 351-376.

Fauconnier, G. \& Turner, M. (2000). Compression and global insight. In Cognitive linguistics, 11, p. 283-304.

Fauconnier, G. \& Turner, M. (2002). The way we think: conceptual blending and the mind's hidden complexities. New York: Basic Books.

Hakemulder, F. (2006). Foregrounding. In The Pergamon encyclopedia of language and linguistics. Brown, K. (ed.). Oxford: Elsevier, IV, p. 546-547.

Havránek, B. (1967). On the functional stratification of the literary language. In Prague Linguistic Circle: [collection of articles]. Moscow: "Progress" Publishing house, p. 432-443. / Gavranek B. O funktsionalnom rassloenii literaturnogo yazyka. In Prazhskij lingvisticheskij kruzhok: [sbornik statey]. Moskva: Izdatel'stvo "Progress", s. 432-443. / Гавранек Б. О функциональном расслоении литературного языка. In Пражский лингвистический кружок: [сборник статей]. Москва: Издательство "Прогресс", c. $432-443$. 
Jakobson, R.O. (1987). The works on poetics. Moscow: Progress. / Yakobson R.O. Raboty po poetike. Moskva: Progress. / Якобсон P.О. Работы по поэтике. Москва: Прогресс.

Jeffries, L. \& McIntyre, D. (2010). Stylistics. Cambridge: Cambridge University Press. Khazagerov, T.G. \& Shirina, L.S. (1994). General rhetoric: a course of lectures and a dictionary of rhetorical figures. Rostov-on-Don: RU Publishing house. / Khazagerov T.G., Shirina L.S. Obschaya ritorika: kurs lektsij i slovar' ritoricheskikh figur. Rostovna-Donu: Izdatel'stvo RU. / Хазагеров Т.Г., Ширина Л.С. Общая риторика: курс лекций и словарь риторических фигур. Ростов-на-Дону: Издательство РУ.

Kupchyshyna, Yu.A. (2013). The role of tropes in realization of defamiliarization. In Zhytomyr Ivan Franko state university journal, 71 (5), p. 306-309. / Kupchyshyna Yu.A. Rol' tropiv u realizatsiyi ochudnennya. In Visnyk ZhDU imeni Ivana Franka, 71 (5), s. 306-309. / Купчишина Ю.А. Роль тропів в реалізації очуднення. In Вісник ЖДУ імені Івана Франка, 71 (5), с. 306-307.

Kupchyshyna, Yu.A. (2013a). The problem of differentiation of defamiliarization and foregrounding: diachronic aspect. In The man in the field of language (collection of scientific articles). Kaunas: Kaunas faculty of Humanities of Vilnius University, 7, p. 32-42. / Kupchyshyna Yu.A. K probleme differentsiatsii ostraneniya i vydvizheniya: diakhronicheskij aspect. In Chelovek v prostranstve yazyka (sbornik naychnykh statej). Kaunas: Kaunasskij gumanitarnyj facultet Vilnyusskogo universiteta, 7, s. 32-42. I Купчишина Ю.А. К проблеме дифференциации остранения и выдвижения: диахронический аспект. In Человек в пространстве языка (сборник научных статей). Каунас: Каунасский гуманитарный факультет Вильнюсского университета, с. 32-42.

Kupchyshyna, Yu.A. (2014). Interpretation of effect of defamiliarization through the prism of conceptual integration. In Scientific notes of the KPUU. Series: Fhilological sciences (linguistics). Kirovograd: RBV KDPU, 127, p. 258-261. / Kupchyshyna Yu.A. Interpretatsiya efectu ochydnennya kriz' pryzmu kontseptualnoyi intergratsiyi. In Naukovi zapysky KDPU. Seriya: Filolohichni nauky. Kirovograd: RVV KDPU, 127, s. 258-261. / Купчишина Ю.А. Інтерпретація ефекту очуднення крізь призму 
концептуальної інтеграції. In Наукові записки КДПУ. Серія: Філологічні науки (мовознавство). Кіровоград: РВВ КДПУ, 127, с. 258-261.

Kupchyshyna, Yu. (2015). Poetics of defamiliarization in English literary texts of XX$X X I$ centuries: linguistic and cognitive aspects. Thesis for the Candidate Degree in Philology, Speciality 10.02.04 - Germanic Languages. Kherson: Kherson State University. / Kupchyshyna Yu.A. Poetyka ochudnennya v anglomovnykh khudozhnikh tekstakh XX-XXI stolit': stylistychnyj ta lingvokognityvnyj aspekty. Dysertatsiya na zdobuttia vchenoho stupenia kandydata filologichnykh nauk. Kherson: Khersons'kij derzhavnyj universytet. / Купчишина Ю.А. Поетика очуднення в англомовних художніх текстах XX-XXI століть: стилістичний та лінгвокогнітивний аспекти. / Дис. ... канд. філол. наук. / Херсон: Херсонський державний університет. 10.02.04 - германські мови.

Lakoff, G. \& Johnson, M. (2003). Metaphors we live by. London: The university of Chicago press.

Lapotaire, J. (2004). Time out of mind. London: Virago, New Ed.

Lapshina, M.N. (2013). Stylistics of modern English language. Moscow: "Academia Publishing" house. / Lapshina M.N. Stilistika sovremennogo angliyskogo yazyka. Moskva: Izdatel'skij tsentr "Akademiya". / Лапшина М.Н. Стилистика современного английского языка. Москва: Издательский центр "Академия".

Leech, G.N. (1969). A linguistic guide in English poetry. London: Longman.

Leech, G.N. \& Short, M. (2007). Style in fiction. A linguistic introduction to English fictional prose. London: Pearson Longman.

Leech, G.N. (2008). Language in literature. Style and foregrounding. London: Pearson Longman.

Lehman, J. (1975). Virginia Woolf. New York: Thames and Hudson.

Levin, S.R. (1965). Internal and external deviation in poetry. In Word, 21, p. 225-237.

Available at: http://dx.doi.org/10.1080/00437956.1965.11435425

Margolin, U. (2005). Russian formalism. In The Johns Hopkins guide to literary theory and criticism. Groden, M., Kreiswirth, M. \& Szeman, I. (eds.). Baltimore: The Johns Hopkins University Press. 
Maslova, V.A. (1991). Parameters of text expressiveness. In The human factor in the language. Language mechanisms of expressiveness, p. 179-205. / Maslova V.A. Parametry ekspressivnosti teksta. In Chelovecheskij faktor v yazyke. Yazykovye mehanizmy ekspressivnosti, s. 179-205. / Маслова В.А. Параметры экспрессивности текста. In Человеческий фактор в языке. Языковые механизмы экспрессивности, c. $179-205$.

Mathesius, V. (1967). On the need for the stability of the literary language. In Prague linguistic circle: [collection of articles]. Moscow: "Progress" Publishing house, p. 378393. / Matezius V. O neobkhodimosti stabilnosti literaturnogo yazyka. In Prazhskij lingvisticheskij kruzhok: [sbornik statej]. Moskva: Izdatel'stvo "Progress", s. 378-393. / Матезиус В. О необходимости стабильности литературного языка. In Пражский лингвистический кружок: [сборник статей]. Москва: Издательство "Прогресс", c. 378-393.

McIntyre, D. (2003). Using foregrounding theory as a teaching methodology in a stylistics course. In: Style, 37, 1, p. 1-20.

Miall, D.S. \& Kuiken, D. (1994). Foregrounding, defamiliarization, and affect: Response to literary stories. In Poetics, 22, p. 389-407. Available at: http://www.ualberta.ca/ dmiall/MiallPub/Miall_Kuiken_Foregrounding_1994.pdf.

Mukařovský, Ja. (1967). Literary language and poetic language. In Prague linguistic circle: [collection of articles]. Moscow: "Progress" Publishing house, p. 406-431. I Mukarzhovskyj, Ya. Literaturnyj yazyk i poeticheskij yazyk. In Prazhskij lingvisticheskij kruzhok: [sbornik statey]. Moskva: Izdatel'stvo "Progress", s. 406-431. / Мукаржовский, Я. Литературный язык и поэтический язык. In Пражский лингвистический кружок: [сборник статей], Москва: Издательство "Прогресс", c. $406-431$.

Mukařovský, Ja. (1996). The structural poetics. Moscow: School "Yazyki russkoj kultury". / Mukarzhovskij Ya. Strukturalnaya poetika. Moskva: Shkola "Yazyki russkoy kultury". / Мукаржовский Я. Структуральная поэтика. Москва: Школа "Языки русской культуры". 
Novikova, M.L. (2005). Defamiliarization as the basis of figurative language semantics and structure of literary text. Moscow: RUDN Publishing house. / Novikova M.L. Ostranenie kak osnova obraznoj yazykovoj semantiki i struktury khudozhestvennogo teksta. Moskva: Izdatel'stvo RUDN. / Новикова М.Л. Остранение как основа образной языковой семантики и структуры художественного текста. Москва: Издательство РУДН.

O. Henry. (1908). The voice of the city: further stories of the four million. South Australia: University of Adelaide. Available at:

https://ebooks.adelaide.edu.au/h/henry/o/voice-of-the-city/

O. Henry. (1907). The trimmed lamp: and other stories of the four million. South Australia: University of Adelaide. Available at:

\section{https://ebooks.adelaide.edu.au/h/henry/o/trimmed-lamp/index.html}

Oleynikova, G.O. (2013). The device of cognitive defamiriliazation in methodology of science fiction. In Odessa linguistic collection, 2, p. 108-114. / Olejnikova G.O. Priyom kognitivnogo ostraneniya v metodologii nauchnoj fantastiki. In Odesskij lingvisitcheskij zbornik, 2, s. 108-114. / Олейникова Г.О. Прием когнитивного остранения в методологии научной фантастики. In Одесский лингвистический сборник, 2, с. 108-114.

Panasenko, N. (2014). Reflection of the naïve Christian worldview in the Romance, Germanic and Slavic phytonymic lexicon. In European journal of science and theology, 10 (4), p. 167-183.

Panasenko, N. (2015). Literary text in the language classroom. In The Magic of innovation: New techniques and technologies in teaching foreign languages: materials of the $2^{\text {nd }}$ scientific-practical conference (Moscow, April, 24-25, 2015). Vol. 2. Kryachkov, D. (ed.). Moscow State Institute of Foreign Relations (MGIMO University), p. 179-186.

Panasenko, N., Grochalová, P. \& Grochalová, L. (2017). 'War' as piece of hard news in British and Slovak media. In European journal of science and theology, 13 (6), p. 87-100. 
Phillips, B. (2003). "Reality and Virginia Woolf". In The Hudson Review, LVI (3). Available at: http://www.hudsonreview.com/ phillipsbrianAu03.pdf

Riffaterre, M. (1980). Criteria for stylistic analysis. In New in foreign linguistics, 9, p. 69-98. / Riffater M. Kriterii stilisticheskogo analiza. In Novoe $v$ zarubezhnoj lingvistike, 9, s. 69-98. / Риффатер М. Критерии стилистического анализа. In Новое в зарубежной лингвистике, 9, с. 69-98.

Schirova, I.A. (2009). Text in the period of dominance of cognitive sciences: problems and possible solutions. In Horizons of modern linguistics: traditions and innovation: dedicated to E.S. Koubriakova. Moscow: Yazyki slavianskikh kultur, p. 723-735. I Schirova I.A Tekst $\mathrm{v}$ period dominirovaniya kognitivnykh nauk: problemy i vozmozhnyye resheniya. In Gorizonty sovremennoj lingvistiki: traditsii i novatorstvo: sbornik v chest E.S. Koubriakovoj, Moskva: Yazyki slavianskikh kultur, s. 723-735. / Щирова И.А. Текст в период доминирования когнитивных наук: проблемы и возможные решения. In Горизонты современной лингвистики: традиџии и новаторство: сборник в честь Е.С. Кубряковой, Москва: Языки славянских культур, с. 723-735.

Schirova, I.A. \& Goncharova, E.A. (2007). Multidimensionality of the text: comprehension and interpretation. St. Petersburg: OOO "Knizhnyj dom". / Schirova I.A., Goncharova E.A Mnogomernost teksta: ponimanie i interpretatsiya. SanktPeterburg: OOO "Knizhnyj dom". / Щирова И.А., Гончарова Е.А. Многомерность текста: понимание и интерпретация. Санкт-Петербург: ООО "Книжный дом". Shklovsky, V. (1990). Art as device. In Theory of prose. Benjamin, S. (ed.). Dalkey Archive Press, p. 58-72.

Shklovsky, V. (1929). Art as technique. In Literary theory: an anthology. Rivkin, J. \& Ryan, M. (eds.). Malden: Blackwell Publishing Ltd, p. 7-23.

Short, M. (1996). Exploring the language of poems, plays and prose. London and New York: Longman.

Simpson, P. (2004). Stylistics: a resource book for students. London-New York: Routledge.

Sotirova, V. (2016). The Bloomsbury companion to stylistics. London: Croom Helm. 
Stockwell, P. (2002). Cognitive poetics: an introduction. London: Routledge.

Turner, M. (2007). Conceptual integration. In: The Oxford handbook of cognitive linguistics. Cuyckens, H. \& Geeraerts, D. (eds.). Oxford: Oxford University Press, p. 377-393.

Uberman, A. (2016). Death in metaphorical language. In Lege artis. Language yesterday, today, tomorrow. The journal of University of SS Cyril and Methodius in Trnava. Warsaw: De Gruyter Open, vol. I (2), December 2016, p. 171-211. DOI: 10.1515/lart-2016-0013 ISSN 2453-8035

van Peer, W. (1986). Stylistics and psychology: Investigations of foregrounding. London: Croom Helm.

Vetvinskaya, T.L. (1975). The principle of "defeated expectancy" as the basis for a stylistic device (case study of English language). In Studies on the Romance and Germanic philology. Kyiv: Vyscha shkola, p. 71-75. / Vetvinskaya T.L. Printsip "obmanutogo ozhidaniya" kak osnova stilisticheskogo priyoma (na materiale angliyskogo yazyka). In Issledovaniya po romanskoj i germanskoj Filologii. Kyyiv: Vyscha shkola, s. 71-75. / Ветвинская Т.Л. Принцип "обманутого ожидания" как основа стилистического приема (на материале английского языка). In Исследования по романской и германской филологии. Київ: Вища школа, с. 7175 .

Vorobyova, O.P. (2005). "The mark on the wall" and literary fancy: a cognitive sketch. In Cognition and literary interpretation in practice. Pettersson, B., Polvinen, M. \& Veivo, H. (eds.). Helsinki: Helsinki University Press, p. 201-217.

Vorobyova, O.P. (2017). 'Haunted by ambiguities' revisited: in search of a metamethod for literary text disambiguation. In Lege artis. Language yesterday, today, tomorrow. The journal of University of SS Cyril and Methodius in Trnava. Warsaw: De Gruyter Open, vol. II (1), June 2017, p. 428-496. DOI: 10.1515/lart-2017-0011

Woolf, V. (1972). "The lady in the looking-glass: a reflection". In: A haunted house and other stories. San Diego: Harcourt Inc., p. 87-93.

Zykova, I. (2016). The phraseological meaning construal in the traditional vs. cognitive culture-oriented perspectives. In Lege artis. Language yesterday, today, tomorrow. The 
journal of University of SS Cyril and Methodius in Trnava. Warsaw: De Gruyter Open, vol. I (2), December 2016, p. 253-286. DOI: 10.1515/lart-2016-0015 ISSN 2453-8035



\section{Résumé in English}

The article highlights the issue of ambiguity of the terms defamiliarization, foregrounding, and defeated expectancy through linguistic and cognitive analysis. The case study is to examine existing linguistic theories of developing the notions mentioned above, proving their interrelation. Defamiliarization and defeated expectancy - are special devices that have great impact on the reader: the usage of such devices in a literary text is undoubtedly connected with their ability to evoke certain associations in a recipient's imagination and prolong related emotions. The authors regard defamiliarization and defeated expectancy as reader's reaction to the deviation from established rules and norms. Deviation of the norm can occur at various levels of 
language functioning - morphological, phonetic, syntactic, etc. The key principle of defamiliarization is a special type of author's consciousness, which is actualized in defamiliarized images through unusual angles of narrator's vision (anthropocentric, animalistic, and cosmic), which in turn influences the mechanisms of the imagery formation in a literary text. Defeated expectancy leads to the conflict that can mainly occur at plot and semantic level of the literary text, i.e. when there is a violation of predictability of events. The research of defamiliarization and defeated expectancy is defined as a combination of traditional linguistic analysis with the techniques of cognitive linguistics (mental space theory, blending). The major manifestations of these devices are considered to be biomorphic, anthropomorphic and zoomorphic metaphors, simile, hyperbole, irony, etc.; syntactic devices (frame repetition, etc.); figures of contrast (antithesis, paradox, etc.). As a result of mental processes, it leads to an expansion, a change in existing knowledge models, or the formation of new models based on stereotypes, which is accompanied by the activation of reader's imagination and the emergence of novel senses, unpredictable textual interchanges.

Key words: perception, angle of vision, defamiliarization, foregrounding, defeated expectancy, linguo-stylistic aspect, cognitive aspect, stylistic device.

\section{Résumé in German}

Dieser Artikel beschäftigt sich mit den Begriffen Verfremdung, Hervorhebung, und enttäuschte Erwartung. Im Besonderen wird geschaut, wie sie in sprachwissenschaftlichen Theorien behandelt werden und wie sie zusammenhängen. Verfremdung und enttäuschte Erwartung sind spezielle Mittel, die einen großen Einfluss auf den Leser bewirken, sie rufen Assoziationen und Emotionen hervor. Der Effekt wird dadurch bewirkt, dass von Regeln und Normen abgewichen wird. Die Normverletzung kann auf verschiedenen Ebenen der Sprache (morphologisch, phonetisch, syntaktisch usw...) auftreten. Der Verfremdungseffekt beruht auf einem speziellen Typ des Autorenbewustseinns, das zu ungebräuchlichen Perspektiven (antropozentrisch, animalisch und kosmisch) führt, was wiederum seinen Effekt auf 
die Bildgestaltung im literarischen Text hat. Enttäuschte Erwartung manifestiert sich auf dem semantischen Niveau und hinsichtlich der Entwicklung des Plots eines literarischen Textes. In diesem Aufsatz werden Verfremdung und enttäuschte Erwartung mit Hilfe von traditionellen Begriffen aus der Sprachwissenschaft analysiert, angereichtert mit Analysetechniken aus der kognitiven Linguistik, wie 'mental space theory' und 'blending'. Es wird gezeigt, dass die Mittel der Verfremdung und enttäuschten Erwartung dazu führen, dass im Text folgende Phänomene auftreten: antropomorphische und biomorphische Metapher, Simile, Hyperbel, Ironie usw.; syntaktische Verfahren wie Wiederholung von Frames; Kontrastfiguren (Antithese, Paradox usw.). Diese Mittel bewirken Änderungen in bestehenden Wissensmodellen oder auf Stereotypen basierte neue Modelle, die von neuen Bedeutungen und Bildern auf der Seite des Lesers begleitet werden.

Stichwörter: Verfremdung, Hervorhebung, enttäuschte Erwartung, kognitiver Aspekt, stilistischer Ansatz.

\section{Résumé in French}

Cet article est dédié au problème de l'ambiguïté des termes l'étrangeté, la mise en avance et l'effet de l'attente trompée à travers le prisme de l'analyse linguistique, stylistique et cognitive. Le but de notre recherche est d'étudier en détail les théories linguistiques courantes de la formation des notions ci-dessus mentionnées en éprouvant leur connexité. L'étrangeté et l'effet de l'attente trompée sont des moyens particuliers qui influencent le lecteur: grâce à l'emploi de tels moyens linguistiques dans une oeuvre d'art le lecteur fait des associations déterminées et éprouve des émotions prolongées. De notre point de vue, l'étrangeté et l'effet de l'attente trompée peuvent être considérés comme une réaction du lecteur ou de l'auditeur contre l'écartement des règles déterminées. Le dérèglement peut avoir lieu aux différents niveaux du fonctionnement de la langue - morphologique, phonétique, syntaxique. La base de l'effet de l'étrangeté c'est le type particulier de la conscience d'auteur qui s'effectue en images d'étrangeté à travers la perspective de la vision des agents du récit (anthropocentrique, animaliste, 
cosmique), ce qui influence les mécanismes de la formation du caractère imagé du texte. L'effet de l'attente trompée mène à un conflit qui surgit aux niveaux sémantique et de sujet, c'est-à-dire quand la prédictibilité des événements est déréglée. Le schéma de l'analyse de l'étrangeté et de l'attente trompée se détermine par la combinaison des moyens de l'analyse linguistique et stylistique traditionnelle avec un mécanisme méthodologique de la linguistique cognitive ( théorie de l'espace mental, blending). Les moyens en question se manifestent à l'aide de différents moyens stylistiques (méthaphores anthropomorphes, biomorphes, zoomorphes, comparaisons d'art, hyperbole, ironie, ainsi que des moyens syntaxiques (répétition de cadre) et ceux de contraste (antithèse, paradoxe). Grâce aux procédés de mentalité on développe et on change des schémas stéréotypes des connaissances et on fait de nouveaux schémas ce qui mène à l'activation de l'imagination du lecteur et à la formation des images d'étrangeté ainsi que des dénouements imprévisibles.

Mots-clés: perception, perspective de la vision, étrangeté, mise en avance, effet de l'attente trompée, aspect linguistique et stylistique, aspect cognitif, moyen stylistique.

\section{Résumé in Russian}

Статья посвящена проблематике неоднозначности терминов остранение, выдвижение и эффект обманутого ожидания сквозь призму лингвостилистического и когнитивного анализа. Цель исследования состоит в том, чтобы детально рассмотреть существующие лингвистические теории создания вышеуказанных понятий, доказав их взаимосвязанность. Остранение и эффект обманутого ожидания - это особые приемы, которые оказывают большое влияние на читателя: само по себе использование таких лингвистических приемов в художественном тексте непременно связано с их способностью вызывать у реципиента определенные ассоциации и продлевать связанные с ними эмоции. Авторы рассматривают остранение и эффект обманутого ожидания как реакцию читателя или слушателя на отступление от установленных правил и норм. Нарушение нормы может происходить на 
различных уровнях функционирования языка - морфологическом, фонетическом, синтаксическом и т.д. В основе эффекта остранения - особый тип авторского сознания, который актуализируется в остраненных образах сквозь ракурс видения субъектами повествования (антропоцентрический, анималистский и космический), что в свою очередь влияет на механизмы формирования образности художественного текста. Эффект обманутого ожидания приводит к конфликту, который может возникать на сюжетном и семантическом уровне, т.е. при нарушении предсказуемости событий. Предполагаемая схема анализа остранения и обманутого ожидания определяется как сочетание приемов традиционного лингвостилистического анализа с методологическим аппаратом когнитивной лингвистики (теория ментальных пространств, блендинг). Доказано, что анализируемые приемы проявляются с помощью различных стилистических приемов (антропоморфные, биоморфные и зооморфные метафоры, художественное сравнение, гипербола, ирония, и др.); синтаксических приемов (рамочный повтор, и др.); фигур контраста (антитеза, парадокс, и др.). В результате ментальных процессов происходит расширение, изменение стереотипных схем знаний, или же создание новых схем на основе предшествующих, что сопровождается активацией воображения читателя и порождением остраненных образов, непредсказуемых текстовых развязок.

Ключевые слова: восприятие, ракурс видения, остранение, выдвижение, эффект обманутого ожидания, лингвостилистический аспект, когнитивный аспект, стилистический прием.

Article was received by the editorial board 02.11.17.

Reviewed 06.11.17. and 07.11.17.

Similarity Index 23\% 